\title{
Dissection of the aorta in Turner's syndrome
}

\author{
W H PRICE AND J WILSON \\ From the MRC Clinical and Population Cytogenetics Unit, and the University Department of Medicine, \\ Western General Hospital, Edinburgh.
}

SUMmARY Three deaths from dissection of the aorta in a series of 157 adult women with Turner's syndrome are reported. These are greatly in excess of the numbers expected. None of the three patients had a coarctation of the aorta. One had aortic regurgitation but there was no reason to believe that the aorta in the other two patients had been subjected to unusual haemodynamic stresses. Cystic medial necrosis of the aorta was described in two patients on whom necropsies were carried out. It is concluded that there is probably a greatly increased risk of dissection of the aorta in Turner's syndrome even in the absence of any other abnormality of the aorta and aortic valve. Previously reported cases of aortic dissection in Turner's syndrome are discussed.

Dissection of the aorta is not a widely recognised complication of Turner's syndrome (TS), although it has been reported in at least seven patients. ${ }^{1-7}$ In all but two of these ${ }^{47}$ there was an associated coarctation of the aorta. In this paper we describe three TS patients who died from dissection of the aorta but who had no evidence of coarctation.

\section{Study population and case reports}

The deaths occurred among 157 adult women with TS who have been observed for an average of 13 years. During that time 13 have died. The 157 patients had been reported to the Edinburgh MRC Cytogenetics Registry since 1959. They all had the clinical features of TS and the following chromosome abnormalities: 45,X (83); 46,XiXq (12); 45,X/ 46,XiXq (19); 45,X/46,XY (13); 46,XdelX(p) (5); $45, X / 46, X+r(7) ; 45, X / 46, X m a r X(4) ; 45, X / 46, X r X$ Received for publication 27 May 1982.
(5); other mosaics (9). A breakdown of years at risk by 10 -year age periods and the number of deaths are shown in the table. In addition to the three patients described in this paper, a fourth who had a coarctation died from dissection of the aorta.

CASE $1(2 / 62)$

This patient was born in Scotland on 5.9.42. Redundant folds of skin were noted at birth and excised at the age of 11 years. She suffered from pneumonia at the age of 5 years and was investigated for primary amenorrhoea at the age of 20 years. Nuclear sex chromatin was negative and chromosome analysis of peripheral leucocytes showed $45, X$. At laparotomy, no ovarian tissue was found. The patient was seen again shortly after she married aged 29 years. She was $132 \mathrm{~cm}$ in height and weighed $41 \mathrm{~kg}$. Her sitting height was $72.5 \mathrm{~cm}$ and span was $138.5 \mathrm{~cm}$. She still had webbing of the neck, the nipples were widely spaced, and the breasts under-

TABLE Years at risk and deaths from dissection of the aorta in 157 adult patients with Turner's syndrome. and mortality from aortic dissection per 100000 of the Scottish female population.

\begin{tabular}{|c|c|c|c|c|c|c|c|}
\hline & \multicolumn{7}{|c|}{ Age group } \\
\hline & $15-24$ & $25-34$ & $35-44$ & $45-54$ & $55-64$ & $65-74$ & $75+$ \\
\hline \multicolumn{7}{|l|}{ Years at risk for 157} & 0 \\
\hline Deaths from dissection & & & & & & & \\
\hline of the aorta & $1^{*}$ & 1 & 2 & 0 & 0 & 0 & 0 \\
\hline $\begin{array}{l}\text { Approximate annual } \\
\text { mortality rate per } \\
100000 \text { of Scottish } \\
\text { female population }\end{array}$ & $0 \cdot 5$ & $0 \cdot 3$ & $1 \cdot 3$ & 3 & 13 & 27 & 48 \\
\hline
\end{tabular}

*This patient also had coarctation of the aorta. 
developed. The external genitalia were prepubertal and the growth of pubic hair sparse. Her IQ (WAIS full scale) was 85 . Her blood pressure was $107 / 73$ $\mathrm{mmHg}$ and no cardiovascular abnormality was detected. Chest $x$-ray and electrocardiogram were both normal. An intravenous urogram showed a horseshoe kidney with a duplex pelvis on one side. She was started on oestrogen replacement therapy with cyclical ethinyloestradiol. She remained well until 14.10.81 when she suddenly developed a severe retrosternal pain when walking up stairs. It was accompanied by light-headedness and paraesthesiae in the hands. The pain lasted for $\mathbf{2 0}$ minutes and was followed by a persistent dull ache. She was admitted to hospital with a suspected myocardial infarction but an ECG was normal. She died suddenly 2 days later. At necropsy there was a dissection of the aorta which had ruptured into the pericardial sac. The dissection between the adventitia and media extended over the arch to the lower thoracic aorta and along the left carotid artery as far as the bifurcation. There was a tear in the intima encircling the aorta $3 \mathrm{~cm}$ above and parallel to the aortic valve ring. There was puckering of the intima at the level of the ductus arteriosus but no coarctation of the aorta.

\section{CASE $2(40 / 62)$}

This patient was born in Scotland on 10.1.36. She presented at the age of 26 years with primary amenorrhoea and failure to develop secondary sexual characteristics. She was unmarried and worked as a cotton mill machine operator. The nuclear sex was chromatin negative and the karyotype of peripheral leucocytes was $45, X$. A diagnosis of gonadal dysgenesis and TS was made and no further investigations were carried out. Replacement therapy was not instituted. At the age of 36 years she was $141 \mathrm{~cm}$ in height and weighed 60.5 kg. Her sitting height was $77 \mathrm{~cm}$ and span was $143 \mathrm{~cm}$. There was webbing of the neck, the nipples were widely spaced, and the breasts underdeveloped. The external genitalia were prepubertal. The blood pressure was 160/91-73 $\mathrm{mmHg}$. She had bilateral lymphoedema, the JVP was normal, the cardiac impulse was normal, and the apex beat was not displaced. The first and second heart sounds were normal but there was a loud early diastolic murmur at the left sternal edge. There was no radiofemoral delay and the peripheral pulses were normal. The chest $x$-ray and electrocardiogram were normal.

Two years later she complained of shortness of breath and she had clinical and ECG evidence of left ventricular hypertrophy. Left heart catheterisation and coronary angiography were carried out. These showed a marked degree of aortic regurgitation and dilation of the ascending aorta. There was no coarctation. Aortic valve replacement was recommended but while awaiting surgery she was readmitted to hospital with a history of retrosternal chest pain. A diagnosis of myocardial infarction was suspected but the ECG was normal and there was no change in serial cardiac enzyme levels. Four days after admission to hospital she complained of left sided pleuritic chest pain and developed clinical and radiological evidence of a left sided pleural effusion. Twenty-four hours later she again complained of severe pain in her chest and in her legs and rapidly lost consciousness. A clinical diagnosis of dissection of the aorta was made and she died after unsuccessful attempts at resuscitation. Permission for necropsy was refused.

CASE $3(98 / 65)$

This patient was born in England on 22.9.45. At the age of 20 years she was referred to hospital with a history of primary amenorrhoea, failure of development of secondary sexual characteristics, and swelling of the left foot of 3 months' duration. She was $145 \mathrm{~cm}$ in height and weighed $69.5 \mathrm{~kg}$. Her sitting height was $76 \mathrm{~cm}$ and span was $147.5 \mathrm{~cm}$. She had a low nuchal hairline, no neck webbing, and only very slight breast development. Nipples were infantile and external genitalia prepubertal. Her IQ was 69 . The blood pressure was $114 / 76 \mathrm{mmHg}$ and no cardiovascular abnormality was detected. A chest $x$-ray and electrocardiogram were normal. Nuclear sex was chromatin negative and the karyotype of peripheral leucocytes and skin fibroblasts showed the presence of two cell lines. The majority of cells had a $45, X$ karyotype but between 10 and $20 \%$ of cells, while lacking a medium sized chromosome, had a small ring chromosome. It was not possible to decide whether the ring was derived from $\mathrm{X}$ or $\mathrm{Y}$ chromosome material. Hormone replacement therapy was not instituted. She subsequently remained well but was found dead in bed at the age of 30 years. Following a necropsy and a coroner's inquest death was attributed to a haemopericardium, owing to a dissecting aneurysm of the aorta, due to Erdheim's medial necrosis.

\section{Discussion}

The mortality each year from dissection of the aorta among Scottish women aged 15 to 55 years is of the order of 1 to 2 per 100000 . It is very improbable, therefore, that three deaths from dissection of the aorta among 157 women with TS in this age group have occurred by chance. Also there are at least seven previously reported cases. It is true that five of these had an associated coarctation of the aorta, an 
anomaly that is not uncommon in TS and one that is not infrequently complicated by dissection. ${ }^{8}$ However, only three of these had a haemodynamically significant coarctation ${ }^{2-4}$ and none of the three women described in this paper had any evidence of coarctation. Dissection of the aorta appears, therefore, to be a particular hazard for TS patients and although the risk is probably accentuated by coarctation it is greatly increased even when the aorta appears normal beforehand. The immediate cause of dissection of the aorta in young people is often cystic medial necrosis. ${ }^{9}$ This histological appearance has been described in at least four of the previously reported cases $^{13-5}$ and in two of the patients described in this paper. Cystic medial necrosis may also be associated with the condition of bicuspid aortic valve which was noted in three of the reported TS cases, ${ }^{3-5}$ and with aortic dilation and regurgitation..$^{10}$ In two of our patients and in at least one of the reported cases ${ }^{7}$ there was no evidence of either an aortic coarctation or of an aortic valve abnormality. Systemic hypertension was noted in four of the reported cases, ${ }^{25-7}$ but was not recorded in any of the three patients described in this paper.

In Marfan's syndrome (MS) and Ehlers-Danlos syndrome (EDS), both of which have a greatly increased risk of dissection of the aorta usually attributed to degenerative changes in the aortic wall, ${ }^{11}$ the underlying defect is believed to be a disorder of collagen biosynthesis. ${ }^{12}$ Attention was drawn to similarities between EDS and TS as long ago as 1951 by Rossi and Caflisch ${ }^{13}$ and Rossi and Angst, ${ }^{14}$ but we know of no report of a collagen abnormality in TS.

An increased risk of dissection renders TS patients more than usually susceptible to the abnormal haemodynamic stresses of aortic valve disorder and coarctation. It would seem advisable, therefore, to intervene promptly and perhaps earlier than might otherwise seem necessary to correct such abnormalities. Regular monitoring of the diameters of the aortic root in TS patients would also seem a reasonable precaution.

We are grateful to numerous consultants and general practitioners who have referred patients with Turner's syndrome to the Edinburgh MRC Unit and who regularly keep us informed about their patients; to Dr P S Andrews for the necropsy report on patient 1 and to Dr A H Kitchin who carried out the cardiac catheterisation on patient 2 . We are also grateful to past and present colleagues in the MRC Unit and in particular to Mrs Anna Frackiewicz, Mrs Susan Collyer, and Mrs Rhona De Mey in the registry of abnormal karyotypes.

\section{References}

1 Salgado CR. Sindrome de Turner: comunicacion de un caso asociado con aneurisma disecante de la aorta. Rev Fac Cienc Med Cordoba 1961 ;19:193-204.

2 Anabtawi IN, Ellison RG, Yeh TJ, Hall DP. Dissecting aneurysm of aorta associated with Turner's syndrome. J Thorac Cardiovasc Surg 1964;47:750-4.

3 Youker JE, Benson BR. Aneurysm of the aortic sinuses and ascending aorta in Turner's syndrome. Am J Cardiol $1969 ; 23: 89-93$.

4 Kostich ND, Opitz JM. Ullrich-Turner syndrome associated with cystic medial necrosis of the aorta and great vessels. Am J Med 1965;38:943-9.

5 Strader WJ, Wachtel HL, Lundberg GD. Hypertension and aortic rupture in gonadal dysgenesis. $J$ Pediatr $1971 ; 79: 473-5$

6 Jeresaty RM, Subrata KB, Franco J. Dissecting aneurysm of the aorta in Turner's syndrome. JAMA 1972;222: 574-6.

7 Miller JM, Herrera EL, Puga UC, Torres GS. Sindrome de Turner y aneurisma disecante de la aorta: presentacion de un caso. Arch Inst Cardiol Mex 1974;44:771-5.

8 Reifenstein GH, Levine SA, Gross RE. Coarctation of the aorta: a review of 104 autopsy cases of the "adult type", two years of age or older. Am Heart J 1947;33: $146-52$.

9 Gore I. Dissecting aneurysms of the aorta in persons under 40 years of age. Arch Pathol $1953 ; 55: 1-14$.

10 McKusick VA, Logue RB, Bahnson HT. Association of aortic valvular disease and cystic medial necrosis of the ascending aorta. Circulation 1957;46:188-91.

11 McKusick VA. Heritable disorders of connective tissue. 3rd ed. St Louis: Mosby, 1972.

12 Prockop DN, Kivivkko KI, Tuderman L, Guzman NA. The biosynthesis of collagen and its disorders. $N$ Engl $J$ Med $1981 ; 301: 77-85$.

13 Rossi E, Caflisch A. Le syndrome du pterygium; status Bonnevie-Ullrich, dystrophia brevicollis congenita, syndrome de Turner et arthromyodysplasia congenita. Helv Paediatr Acta $1951 ; 6: 119-48$.

14 Rossi E, Angst H. Das Ehlers-Danlos syndrom. Helv Paediatr Acta $1951 ; 6: 245-54$.

Requests for reprints to Dr W H Price, MRC Clinical and Population Cytogenetics Unit, Western General Hospital, Edinburgh EH4 2XU. 
susceptibility to a particular disorder. The data presented here on PGM and tuberculosis lead one to suspect that discovery of true associations of gene markers and disease must await establishment of more refined techniques of gene identification, such as that of isoelectric focusing used here or of DNA probes currently in process of development.

The authors are grateful to Professor D F Roberts for his suggestions during this work and his perusal of the manuscript.

\section{References}

1 Selby R, Barnard JM, Buehler SK, Crumley J, Larsen B, Marshall WH. Tuberculosis associated with HLA-B8, BrS in a Newfoundland community study. Tissue Antigens $1978 ; 11: 403-8$.

2 Khomenko AG, Averbach MM, Kalankhodzhaev AA, Malenko AF, Chukanova VP, Moroz AM. Distribution of HLA antigens in tuberculosis patients. Ter Arkh $1980 ; 53: 135-8$

3 Mourant AE, Kopec AA, Domaniewska-Sobczak K. Blood groups and disease. Oxford: Oxford University Press, 1978.

4 Kooptzoff O, Walsh RJ. Blood groups and diseases: pulmonary tuberculosis. Aust Ann Med 1957;6:53-5.

5 Milunicova A, Dominec M. Blood characteristics and PTC test in young patients suffering from pulmonary tuberculosis and diabetes mellitus. Rozhl Tuberk 1966; 26:545-50.

${ }^{6}$ Hever O. Rélations entre les phénotype d'haptoglobine dans diverses maladies. Presse Med 1969;77:1081-2.
7 Sidhu LS, Singh J, Bhatnagar DP, Pahuja JK. Association of pulmonary tuberculosis with $\mathrm{ABO}$ and $\mathrm{Rh}(\mathrm{D})$ blood groups. In: Sanghvi LD et al, eds. Population genetics in India. India: Orient Longman, 1974;135-40.

8 Karim AKMB, Elfellah MS, Evans DAP. Human acetylator polymorphism: estimation of allele frequency in Libya and details of global distribution. $J$ Med Genet $1981 ; 18: 325-30$.

9 Constans J, Viau M. Group-specific component: evidence of two subtypes of $\mathrm{Gc}^{1}$ gene. Science 1977;198:1070-1.

10 Bark JE, Harris MJ, Firth M. Typing of the common phosphoglucomutase variants using isoelectric focusing. A new interpretation of phosphoglucomutase system. J Forensic Sci Soc 1976;16:115-20.

11 Papiha SS. Isoelectric focusing in the detection of genetic variation of enzyme and proteins: method and gene frequencies of the group-specific component (Gc) in the Gaddi tribe of Chamba (Himachal Pradesh). J Indian Anthropol Soc 1981;16:75-87.

12 Spencer N, Hopkinson DA, Harris H. Phosphoglucomutase polymorphism in man. Nature 1964;204:742-5.

13 Papiha SS, Roberts DF, White I, Chahal SMS, Asefi AJ. Population genetics of the group-specific component and phosphoglucomutase $\left(\mathrm{PGM}_{1}\right)$ studies by isoelectric focusing. Am J Phys Anthropol 1982;59:1-7.

14 Woolf B. On estimating the relation between blood group and disease. Ann Hum Genet 1955;19:251-3.

15 Haldane JBS. The estimation and significance of the logarithm of a ratio of frequencies. Ann Hum Genet 1955;20:309-11.

Correspondence and requests for reprints to Dr S S Papiha, Department of Human Genetics, 19 Claremont Place, Newcastle upon Tyne NE2 4AA.

\section{Correction}

In the paper by Price and Wilson on "Dissection of the aorta in Turner's syndrome" which was published in the February 1983 issue of the Journal (20:61-3), the last sentence of the first column on the first page should have read: "They all had the clinical features of TS and the following chromosome abnormalities: 45,X (83); 46,X,i(Xq) (12); 45,X/ 46,X,i(Xq) (19); 45,X/46,XY (13); 46,X,del(X)(p) (5); 45,X/46,X, $+r \quad(7) ; 45, X / 46, X, \operatorname{mar}(X) \quad(4)$; $45, X / 46, X, r(X)(5)$; other mosaics (9)". 